\title{
Assessing knowledge of Medical undergraduate students on palliative care in end-stage disease patients
}

\author{
Avaliação dos conhecimentos dos acadêmicos do curso de Medicina sobre os cuidados \\ paliativos em pacientes terminais
}

\author{
Sandra Alamino Felix de Moraes $^{1}$, Maisa Carla Kairalla ${ }^{2}$
}

\begin{abstract}
Objective: To assess the knowledge on palliative care of undergraduate medical students of the $9^{\text {th }}$ and $10^{\text {th }}$ semesters at Universidade Nove de Julho. Methods: A self-applied and self-explanatory questionnaire was prepared with 9 objective questions and given to 50 undergraduate medical students of these semesters. The content was related to palliative care, addressing some topics, such as orthothanasia, dysthanasia, euthanasia and clinical cases. The questionnaire was applied from November 2007 to February 2008. Results: As to correct answers, the rates were $84 \%, 42 \%, 38 \%$ and $40 \%$ to questions $1,2,3$ and 4 , respectively. Question 7 was correctly answered by $84 \%$ and Question 8 by $30 \%$. Question 9 achieved 100\% correct answers. Regarding Question 5, there was no right or wrong answer, and $24 \%$ of the students chose alternative $A, 32 \%$, alternative B and $44 \%$, alternative C. In Question 6 , the students could tick more than one alternative, if necessary: $22 \%$ chose alternative $A, 6 \%$, alternative $B, 2 \%$, alternative $C$, $20 \%$ chose $D$ and $6 \%$ responded alternative $E ; 36 \%$ opted for both alternatives $B$ and $D$, and $6 \%$ of students answered alternatives B, C and D. Conclusions: Medical students that will conclude the undergraduate course are aware of the nature and the importance of palliative care, even when they have no previous experience during training at university.
\end{abstract}

Keywords: Students, medical; Hospice care; Health Knowledge, attitudes, practice

\section{RESUMO}

Objetivo: Avaliar o conhecimento sobre cuidados paliativos dos acadêmicos do curso de Medicina do $9^{\circ}$ e $10^{\circ}$ semestres da Universidade Nove de Julho. Métodos: Foi formulado um questionário autoaplicável e autoexplicativo, com 9 questões objetivas, para 50 alunos desses semestres. 0 conteúdo do questionário referia-se a cuidados paliativos e indagava sobre temas como ortotanásia, distanásia, eutanásiae casoclínico. Aaplicação do questionário ocorreu entre Novembro de 2007 e Fevereiro de 2008. Resultados: 84\% dos alunos responderam a Questão 1 corretamente; $42 \%$ responderam corretamente a Questão 2; 38\% responderam corretamente a Questão 3; $40 \%$ responderam corretamente a Questão 4; $84 \%$ responderam corretamente a Questão 7; 30\% responderam corretamente a Questão $8 ; 100 \%$ responderam corretamente a Questão 9 . Na Questão número 5 , não havia alternativa certa ou errada, portanto, $24 \%$ dos alunos responderam a alternativa $A, 32 \%$ a alternativa $B$ e $44 \%$ a alternativa C. Na Questão 6, 0 aluno poderia responder mais de uma alternativa se achasse necessário: $22 \%$ responderam a alternativa $A ; 6 \%$ responderam a alternativa $B ; 2 \%$ responderam a alternativa $C ; 20 \%$ responderam a alternativa $D ; 6 \%$ responderam a alternativa $E ; 36 \%$ responderam as alternativas $B$ e $D$ e $6 \%$ dos alunos responderam as alternativas B, C e D. Conclusões: Percebeu-se que o estudante de Medicina que concluirá sua graduação está consciente do que é e qual a importância dos cuidados paliativos, mesmo não tendo a vivência durante o período acadêmico.

Descritores: Estudantes de Medicina; Cuidados paliativos; Conhecimentos, atitudes e prática em saúde

\section{INTRODUCTION}

Palliative is a word of Latin origin that means a covering, a blanket, and may also signify that which possesses the capacity to temporarily calm pain, for example ${ }^{(1-2)}$.

By definition, palliative care is an approach that increments the quality of life of patients and their families in which the problem of serious disease is faced by means of prevention and relief of suffering, which means an early identification and accurate assessment for the treatment of pain and physical, psychosocial and spiritual problems ${ }^{(3)}$.

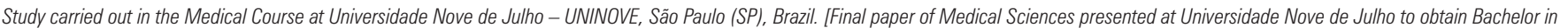
Medicine Degree, 2008].

Medical student at Universidade Nove de Julho - UNINOVE, São Paulo (SP), Brazil.

${ }^{2}$ Professor in the Medical Course at Universidade Nove de Julho - UNINOVE, São Paulo (SP), Brazil.

Corresponding author: Sandra Alamino Felix de Moraes - Avenida Angélica, 412, apto. A - Santa Cecília - CEP 01228-000 - São Paulo (SP), Brasil - Tel.: 11 3667-7643 - E-mail: sandralamino@yahoo.com.br

Received on Aug 13, 2009 - Accepted on Apr 12, 2010
} 
Currently, as per the World Health Organization, 2002, the palliative care promotes relief of pain and other uncomfortable symptoms with the systematic use of adequate analgesic methodology and the prediction of its side-effects.

The palliative care confirms life and considers death a normal process. It has the intention of not rushing or postponing death and integrates psychological and spiritual aspects of patient care. It offers a support system to enable the patient to live as actively as possible until he/she passes away and a support system to aid family members in facing the patient's illness and in dealing with their own mourning. The palliative care uses a multiprofessional approach in order to attend to the needs of the patient and family members, including the accompaniment of mourning and improvement in quality of life, which may positively influence the course of the disease ${ }^{(4)}$.

The palliative care aims to promote orthothanasia, which means the correct conduct in the face of death. It is the appropriate approach in the case of an individual who is dying, offering adequate palliative care measures. It is different from dysthanasia which is slow, anxious death with intense suffering, and from euthanasia, the practice of abbreviating the life of an incurable patient in a controlled manner assisted by a specialist, which is considered a crime by the Brazilian Penal Code and by the Medical Code of Ethics ${ }^{(5)}$.

The first practices of palliative care date back to the fourth century, but the palliative care currently known derives from a movement of consideration of the patient, the hospices ${ }^{(6)}$. The French word hospice is the translation of the Latin word hospitium, which means "housing/hosting", hospitality, translating a feeling of shelter. The hospitium meant the place and bond established among people. A good example of hospice was originated in the sixth century, when the Benedictines cared for exhausted monks and pilgrims. In the same way, when ill people also began to be received at these places, religious hospices were born. In these hospices, people who had no possibility of being cured, received basic care as to food and comfort, allied with spiritual care. Therefore, historically, the hospice represented a place of rest. Posteriorly, the theme was related to hospitals, convents, and asylums ${ }^{(7)}$.

A great movement seeking the approach of nonfragmented care and going beyond the diseased organ or cure, called the modern hospice movement, occurred in the United Kingdom during the 1960's, with the beginning of palliative care. The transformation of hospices, as they are known today, was created by the nurse, social worker and physician, Cicely Saunders, who founded Saint Christopher's Hospice, in England, in 1967, bringing a new dimension to palliative care $^{(6-7)}$.

The palliative care model reached Brazil at the beginning of the 1980's, a phase in which Brazilians still lived in the final days of a dictatorship with a healthcare system that prioritized a hospital-centric modality that was essentially curative. The teaching of Nursing and of Medicine was focused on biological aspects, and projects were predominantly individual, with solitary and inhumane deaths.

Currently, in Brazil, there are 30 palliative care services distributed into 26 states and the Federal District, with greater concentration in capital cities. Most of these services initiated with the objective of managing pain, and posteriorly aggregated this with palliative care centers. These centers are inserted in public hospitals and private clinic institutions ${ }^{(8)}$.

In Brazil, the quality of life of a person with a serious disease with no possibility of cure is critical. More than $70 \%$ of these patients are admitted with pain and are feeble, and $50 \%$ of them die experiencing pain. As inpatients in hospitals and associated healthcare units, most are not treated adequately, i.e., with a right to treatment and medication, and interdisciplinary emotional and psychosocial assistance, which, by the way, would have to be extended to the family members as well if Brazil had a public policy directed towards palliative care $^{(9)}$.

Depending on the conditions of the patient, the objective is to maintain him/her as long as possible at home, since time and quality of life are greater and better with the support of the family; the same team of professionals care for the patient at home, being responsible for treatment, relief of symptoms and even for support and preparation for farewells, alleviating the suffering of all those involved ${ }^{(9)}$.

The World Health Organization emphasizes that active treatment and palliative treatment are not mutually exclusive and proposes that palliative care may be gradually increased as a component of the care of patients from diagnosis until death ${ }^{(3)}$. The lack of investments in palliative Medicine is a result of the scarcity of information in society. It also results from the prejudice of many professionals, the inexistence of public policies and also from the absence of specific medical education ${ }^{(9-10)}$.

Evidence seems to demonstrate that we have forgotten the classic teaching that recognizes the role of the physician as "curing sometimes, relieving very frequently, and comforting always". We have abandoned caring for the ill person and attempt to treat the person's illness, without acknowledging that our primary mission should be that of seeking the physical and emotional well-being of the ill person as every human being will 
always be a complex biopsychosocial and spiritual reality ${ }^{(11)}$.

Medical schools and hospital rotations prepare future physicians to become the main officers of science and managers of complex biotechnology. Very little is taught about the art of being a physician and doctors learn very little about how to deal with death. The most fundamental reality is that there has been a biotechnological revolution that enables the interminable prolonging of life ${ }^{(12)}$.

With the approval of resolution $1.805 / 2006$ as to the finality of life, the General Medical Council works to amplify the scope of palliative care. The objective is to make palliative care a subject taught at Brazilian universities in the same way in which the treatment of disease is taught. This is the ideal manner in which to train further doctors that are more compassionate and dedicated to their patients ${ }^{(9)}$.

With the law of humanization of care and of management, from 2001, it is necessary to verify if future healthcare professionals are being adequately prepared to comply with the law ${ }^{(13)}$.

\section{End of life}

Defining the period of time as "end of life" is difficult, but necessary. Generally, it is not easy to know when the patient is in the final phase of life, since there is no uniformity in definitions in the literature. Viganò et al. ${ }^{(14)}$ defined the beginning of the terminal phase as the period in which the goals primarily established for the treatment and control of the disease need to be redefined for control of symptoms, and they cite three conditions that must be known before defining the disease as terminal: diagnostic confirmation of a progressive malignant disease, recognition of approaching death and exhaustion of all therapeutic alternatives.

Despite the lack of consistency in the literature as to the definition of end of life, survival time usually is not an important final point in palliative care, where the emphasis is on quality and not on quantity of life ${ }^{(15)}$.

\section{Mourning}

Even after the patient's death, the palliative care team should give attention to the discussion of how the entire death process occurred and what impacts it had on family members and even on the multiprofessional team itself ${ }^{(16)}$. Assistance to families after the patient's death may be given in three ways: by means of a telephone call to express condolences, the presence of one of the members of the team at the funeral, or even with participation of families in one of the events promoted by the palliative care team. Another form of assistance may be given by the identification of family members who might benefit from preventive interventions ${ }^{(17)}$. Despite definitions of periods of treatment in cancer and their relationships with palliative care, the possibility of superimposing the groups exists and distinction cannot be exact as the disease progresses or responds to treatment.

Classifications and definitions not based exclusively on disease characteristics, but also on psychological attitudes and on the objectives of the patient, may diminish the conflicts and doubts as to treatment decisions $^{(18)}$.

\section{OBJECTIVES}

The objectives of this paper were to evaluate the knowledge content of undergraduate students of the $9^{\text {th }}$ and $10^{\text {th }}$ semesters of Universidade Nove de Julho medical school as to palliative care of terminally ill patients and assess whether academic medical training addresses this theme with criteria of quality of care.

\section{METHODS}

A self-applied and self-explanatory questionnaire was developed, with questions containing at least three alternatives (in some of these questions, more than one correct answer could be marked) (Appendix 1), targeting 50 medical students of Universidade Nove de Julho, who were in the last $\left(9^{\text {th }}\right.$ and $\left.10^{\text {th }}\right)$ semesters of the course. The student was to begin answering the questionnaire as soon as he/she received it and hand it in as soon as it had been completed. The questionnaire was to be answered with no time limits and in a tranquil environment, with no external noise or interference from other people. Inclusion criteria in this study were the fact of the individual being a medical student at Universidade Nove de Julho and having an interest in participating in the study.

Data were collected from November 2007 to February 2008. The questionnaire contains nine questions concerning dysthanasia, euthanasia, orthothanasia, sheltering and humanization of care, the conduct of physicians/medical teams in face of a clinical case and how well the student is prepared to deal with the death of patients in a caring and compassionate way.

\section{RESULTS}

In Questions 1, 2, 3, 4, 7, 8 and 9, there was only one correct alternative; $84 \%$ of subjects answered Question 1 correctly. As to Question 2, 42\% responded correctly (alternative A), while $4 \%$ answered with alternative B, and $12 \%$ with alternative $\mathrm{C}$. 
In Question 3, 38\% of the students responded correctly with alternative $\mathrm{B}, 44 \%$ responded with alternative $\mathrm{A}$ and $14 \%$ with alternative $\mathrm{C} ; 40 \%$ answered Question 4 correctly - 8\% responded with alternative A as correct, $50 \%$ with alternative $\mathrm{C}$ and $2 \%$ responded with option B. In Question 7, 84\% responded correctly (alternative B), while $6 \%$ marked alternative $\mathrm{A}$ and $10 \%$ option C. In Question 8, 30\% responded correctly (alternative C), $50 \%$ responded with option A, $20 \%$ with option $\mathrm{B}, 0 \%$ with alternative $\mathrm{D}$ and $0 \%$ with answer E; $100 \%$ responded to Question 9 correctly with alternative B $(0 \% \mathrm{~A}, 0 \% \mathrm{c}, 0 \% \mathrm{D}$, and $0 \% \mathrm{E})$.

As to Question 5, there was no correct or incorrect alternative; the student had to answer with the alternative that best reflected his/her personal opinion, and the results obtained were: $24 \%$ responded with alternative A, $32 \%$ with alternative B and $44 \%$ with alternative C.

In Question 6, regarding medical training and palliative care, the student could reply with more than one alternative if he/she considered it necessary. The results found were: $22 \%$ chose only alternative A; $6 \%$ chose only alternative B; $2 \%$ chose only alternative C; $20 \%$ chose only alternative $\mathrm{D} ; 6 \%$ chose only alternative E; $36 \%$ chose alternatives $\mathrm{B}$ and $\mathrm{D}$ and $6 \%$ of the students responded with alternatives $\mathrm{B}, \mathrm{C}$, and $\mathrm{D}$.

\section{DISCUSSION}

Training courses in the area of healthcare, fundamentally for physicians and nurses, have emphasized technical procedures in detriment of a more humanistic education. The procedure of each doctor in approaching serious disease is to make the diagnosis, plan and put into practice the specific cure. This procedure is called by Nuland "the charade". The satisfaction of solving this charade is its own recompense; it is the fuel that makes clinical machinery work in well trained medical specialists. It is the measure of the capacity of each physician; it is the most important ingredient of his/her professional self-image.

Right at the beginning of the first year of medical school, the medical student comes into contact with the cadaver in the dissection room. But the cadaver is not death, it is only the disposable outer casing of the person as a whole, i.e., a person is made up of body, mind and spirit. In reality, death is a process that may be instantaneous or slow, unperceived or of intense suffering. The process of death and dying involves stages, phenomena that antecede clinical death per se.

This first encounter of the medical students with cadavers in the anatomy class generally causes great anguish in some of them. Since the display of feelings is not always socially acceptable, contraphobic manifestations, such as making jokes or showing indifference, are frequently observed ${ }^{(19)}$. Any human identity is removed from the cadaver, since it can be very distressing to manipulate organs if there is the thought that this was once a human being. Human values begin to diminish during medical school, as is stated by Lown ${ }^{(12)}$. The author continues declaring that it is wrong to begin medical training with dissection of cadavers in anatomy class.

To counterbalance the horror of this task, students prefer to consider as an inanimate object the repugnant body that reeks of formaldehyde. This leads them to forget that "that" was previously a human being, just as the live humans that study "it". From then on, and during the entire learning process of this student, a desensitization is noted regarding elements that may enable comprehension of the possibility of death.

The bodies are then transformed into organs, or "parts", such as bones, blood, and their manipulation allows the knowledge and the false idea that in combating the diseases and symptoms, one is also fighting against death. A good part of the feelings of omnipotence may be anchored here ${ }^{(20)}$.

During the six years of medical school, added to those of internship and residence, and for the rest of the person's professional life, physicians, nurses, and other Healthcare professionals will come face-to-face with death on several occasions and circumstances; most of them, depending on their own background, will tend to not accept or comprehend it. They fear death as much as the layperson does. Especially for the physician, that needs to conquer it, annul it, probably in an attempt to distance him/herself from the thought of his/her own finiteness ${ }^{(21)}$. Added to this affirmation, Question 5 shows us that the majority of students declare not feeling prepared to face the death of a patient, but they claim to not associate it with defeat, loss, or frustration. Maybe due to the fact that they have not graduated yet, they do not assume responsibility for a patient they have been accompanying.

There is a need to allow room for sensitization and discussion of the theme of death in training Healthcare professionals, considering that they will encounter the topic in their daily activities. This need is proved by Question 6 that asks the student about what was lacking in the medical school that could adequately prepare $\mathrm{him} / \mathrm{her}$ for assisting the patient and the family members at the time of death. Most of them responded that they felt a lack of a subject that dealt with issues such as the process of death and dying and that there was no room to approach the emotional and social aspects of the human being, such as contact with patients with no possibility of a cure. This shows that the students themselves recognize the deficiency of medical teaching on this theme. 
With this deficiency in academic background, which does not prepare future physicians and healthcare professionals to better understand the process of death and dying, what we observe is a "defective view" when faced by the death of a patient ${ }^{(22)}$.

Question 4 asked if the student considered it important for the terminal patient to die at home amongst family members, and most of them responded that the patient should be the one to choose the location where he/she wished to die, but a small number answered that dying at home meant that the patient did not receive the necessary medical care - maybe this small group felt that they could extend the patient's life until the last moment, possibly enabling a less painful death.

In the clinical case presented in the questionnaire, most of the students responded correctly to Question 7 , in which the alternative stated that the patient has the right to know what is going on with his/her health condition and to choose what he/she desires to do in the time of life he/she still has. On the other hand, Question 8, in which students were inquired regarding the same clinical situation if the bond between the physician and the family would change the situation of the given patient, most students responded yes, but only from the point of view that only the physician could do something different, and not a member of the team who may already have formed a bond with the patient, since palliative care teams are formed by interdisciplinary groups who work together in favor of the patient, and any member of the team has the ability to decide as to what will or will not be best for the patient.

In Question 9, all students agreed that the palliative care team is an interdisciplinary team that follows the axis of humanization and the axis of physical, emotional and spiritual well-being of the patient.

In conceptual issues about orthothanasia, euthanasia and dysthanasia, we noted that most students did not know what dysthanasia meant.

The very concept of palliative care - since it is based on quality of life for the patient and those around him/ her, much more than on the sanctity of life, and since it takes into consideration the entirety of the patient and his/her needs - constitutes a complement or an alternative to so-called "medical positivism", thanks to a greater humanization of practices of treatment and care of those who need it.

In insisting on the integrality of the experience of living, which implies death, this entails a new metaphysical enrichment for the young professional who can also feel more comfort in his/her inevitable professional frustrations.

Palliative care may delineate a type of juste milieu constituted by the concern in responding to the call of another person while, at the same time, not expropriating him/her of the fundamental experience of his/her death ${ }^{(14,23-24)}$.

\section{CONCLUSIONS}

Therefore, according to the study carried out, we noted that the soon-to-graduate medical student will finish training theoretically conscious of the definition and the importance of palliative care - even without having the experience during the medical course - but may not have the practical basis for using a theory which he/ she agrees is important. Consequently, it is important that in the medical syllabus be included a subject that shows the student the correct form of approaching patients under palliative care without the necessity of learning on his/her own or in an inappropriate manner, but rather preparing him/her for the near future when he/she will be the professional who will treat this type of patient.

\section{REFERENCES}

1. Barbosa SMM, Vallente MT, Okay Y. Medicina paliativa: a redefinição da experiência humana no processo de adoecer. Rev Dor. 2001;3(61):61-8.

2. Melo AG. Os cuidados paliativos - uma nova abordagem em evolução no mundo. In: $4^{0}$ Simpósio Brasileiro sobre Dor - SIMBIDOR, 1999. Arquivos. São Paulo; 1999. p. 294-6.

3. World Health Organization. WHO definition of palliative care [Internet]. [cited 2010 Jun 10]. Available from: www.who.int/cancer/palliative/definition/en/

4. Goldim JR. Eutanásia [Internet]. [citado 2010 Jan 20]. Disponível em: www. ufrgs.br/bioetica/eutanasi.htm

5. Conselho Federal de Medicina. Código de Ética Medica. Resolução CFM No 1.931, DE 17 de Setembro de 2009. Diário Oficial da União; Poder Executivo, Brasília, DF, 24 set. 2009. Seção I, p. 90-2. Diário Oficial da União; Poder Executivo, Brasília, DF, 13 out. 2009. Seção I, p. 173 - Retifica.

6. Twycross R. Medicina paliativa: filosofía y consideraciones éticas. Acta Bioeth. 2000;6(1):29-46.

7. Abu-Saad HH, Courtens A. Developments in palliative care. In: Abu-Saad $\mathrm{HH}$, Courtens, A. Evidence-based palliative care: across the life span. Oxford: Blackwel Science; 2001. Chapter 2. p. 4-13.

8. Miguel Jr A. Cuidados paliativos [Internet]. 2007. [citado 2010 Jan 10]. Disponível em: www.medicinageriatrica.com.br/2007/03/23/saude-geriatria/ cuidados-paliativos/

9. Carência no atendimento. Revista APM. 2007;(583):20-21.

10. Schonwetter RS. The emergence of palliative care. Cancer Control. 2001:8(1):3-5. Editorial.

11. Conselho Federal de Medicina. Resolução n. 1805 de 28 de novembro de 2006. [Internet]. Brasília (DF): Diário Oficial da República Federativa; 2006 [citado 2007 Mar 13]. Disponível em: http://www.unimeds.com.br/layouts/ capa/index_1.asp? cod $=14351$ \&site $=192$

12. Lown B. A arte perdida de curar. 2a ed. São Paulo: JSN; 1997

13. Moraes SD. Humanização da assistência materno-neonatal: uma contribuição a sua implantação [tese]. São Paulo: Universidade de São Paulo; 2005.

14. Viganò A, Dorgan M, Buckingham J, Bruera E, Suarez-Almazor ME. Survival prediction in terminal cancer patients: a systematic review of the medical literature. Palliat Med. 2000;14(5):363-74. 
15. Miller RJ. Supporting a cancer patient's decision to limit therapy. Semin Oncol. 1994;21(6):787-91.

16. Ferrell BR, Coyle N. An overview of palliative nursing care. Lippincotts Case Manag. 2002;7(4):163-8.

17. Kissane DW. Bereavement. In: Doyle D, Hanks G, Cherny N, Calman K, editors. Oxford textbook of palliative medicine. 3th ed. New York: Oxford University Press; 2005. p. 1137-51.

18. Levy MH. Supportive oncology: forward. Semin Oncol. 1994;21 (6):699-700.

19. Concone MHB. 0 "vestibular" de anatomia. In: Martins JS, editor. A morte e os mortos na sociedade brasileira. São Paulo. Hucitec; 1983. p. 25-37.
20. Zaidhaft S. A morte e a formação médica. Rio de Janeiro: Francisco Alves; 1990.

21. Figueiredo MT. Educação em cuidados paliativos: uma experiência brasileira. Mundo Saúde. 2003;27(1):165-70.

22. Bifulco VA. Reflexões sobre a morte e o morrer nos atendimentos psicológicos de cuidados paliativos. Prat. Hosp [Internet]. 2004;6(32): [citado 2010 Jun 3]. Disponível em: http://www.praticahospitalar.com.br/pratica\%2032/paginas/ materia\%2009-32.html

23. Levy MH. Supportive oncology: forward. Semin Oncol 1994;21(6):699-700.

24. Ferrell BR, Coyle N. An overview of palliative nursing care. Lippincotts Case Manag. 2002;7(4):163-8.

\section{APPENDIX 1}

\section{Questionnaire}

\section{What is orthothanasia?}

a. It is the appropriate approach in face of a patient that is dying, adopting adequate palliative care offered to patients during their final moments of life.

b. Slow, anxious death with much suffering.

c. It is the practice by which the life of an incurably ill patient is shortened in a controlled manner assisted by a specialist.

2. What is euthanasia?

a. Treatment that adopts adequate palliative care offered to patients during the final moments of life, with judicial support.

b. Slow, anxious death with much suffering.

c. Treatment with medications that cause deep sedation and do not cause suffering for the patient.

3. What is dysthanasia?

a. It is the appropriate approach in face of patient that is dying, adopting adequate palliative care offered to patients during their final moments of life.

b. Treatment that decides on the survival of a patient taking into consideration the opinions of family members.

c. It is the practice by which the life of an incurably ill patient is abbreviated in a controlled manner assisted by a specialist.

4. Do you think it is important for a terminal-stage patient to die in his/her own home, surrounded by family members?

a. Yes, since the patient who is at the end of his/her life deserves to spend the time remaining with his/her family.

b. No, since dying at home means that the patient did not receive the necessary medical care.

c. The patient should choose where he/she wants to die.

d. Alternatives $\mathrm{A}$ and $\mathrm{C}$ are correct.

e. None of the alternatives above.

5. Do you consider yourself prepared to deal with the death of a patient?

a. Yes, I face death as a natural process of life.

b. No, I associate death with defeat, loss, and frustration.

c. No, but I do not associate death with defeat, loss, and frustration.

6. In your opinion, what was lacking in your Medical School training to provide you with adequate preparation for assisting the patient and family members at the time of death? (Answer with more than one alternative, if necessary)

a. Nothing, I feel fully prepared.

b. The inclusion of a subject that deals with some issues, such as the process of death and dying.

c. Sensitization on the part of the lecturers in order to make us think about this type of issue.

d. Room to deal with the emotional, spiritual and social aspects of the human being, as well as contact with the patient who has no possibility of being cured.

e. At the moment, I am not sufficiently mature to opine on this issue.

A 68-year-old patient was admitted to an ICU with serious respiratory failure requiring a respirator. He was fully conscious and was capable of opining on procedures being performed. His sons and wife gave him strong emotional support. On the following day, the medical team made the diagnosis of an irreversible condition with a predicted survival of no more than 30 days. The family was informed of this diagnosis, but the patient was not. His sons asked that this information not be revealed to the patient, since they did not know how he would handle the situation. The medical team complied with this request. In the same way, the sons discussed with the team as to what measures could be taken in order to reduce the patient's suffering. The attending physician, who had no prior bond with the patient or the family, suggested sedating the patient so that the respiratory discomfort would be relieved. The sons and daughters-in-law accepted the suggestion, and the patient was sedated.

7. As to the clinical case described above, do you consider the attitude of the patient's family members regarding the attending physician correct?

a. Yes. In this way the patient would be spared the suffering of knowing that he only had 30 days of life left, besides receiving medications that cause deep sedation, with no suffering for the patient.

b. No. The patient has the right to know what his condition is, to choose how he desires to spend the time he has left, and to receive palliative care already in use in Brazil.

c. I do not think the physician should interfere in the family's decision.

8. Do you think that if the attending physician had had a prior bond with the family, this situation would be different?

a. Yes, since the physician would have prior knowledge of the case, and therefore would help the family seek palliative care and inform the patient of his situation.

b. No; in almost all cases of terminally-ill patients, the end of life occurs in a hospital without palliative care. Most people die without knowing that this type of care exists. The bond of the physician with the family would not change this situation.

c. It does not have to be the physician; any caring member of the team would have prior knowledge of the case, and would therefore help the family to seek palliative care, leaving the patient informed and comforted as to his situation.

d. In this case, the patient does not have the right to opine as to his health.

e. None of the above.

9. A Palliative Care team is an interdisciplinary group formed by professionals who care for a patient in a terminal stage in order for him/her to have a painless death, surrounded by family members, and in his/her home (if the patient prefers). They give the family orientation, helping them to be prepared and know what to do when the time of death comes for the patient. How should this team be prepared?

a. It does not need to be prepared.

b. The ideal team should be interdisciplinary and follow the principle of humanization, with physical, emotional and spiritual well-being of the patient.

c. All members should be college graduates.

d. No family member should be a part of this team.

e. None of the above. 